\title{
EXPERIMENTAL INVESTIGATION OF THERMAL EFFECTS ON THE DRILLING OPERATION OF LOW CARBON STEEL
}

\section{Kasali A. Adedeji, Nurudeen A. Raji, Lukman O. Fadipe, Abdulqudus Giwa}

Mechanical Engineering Department, Lagos State University, Epe, Lagos Nigeria

e- mail: kasali.adedeji@lasu.edu.ng

Received: 23rd August 2018

Accepted: 7th July 2019

Published: 17th September 2019

https://doi.org/10.47545/etrj.2019.4.2.052

\begin{abstract}
The effects of drilling parameters, drill speed and feed rate on the twist drill bit temperature in drilling of low carbon steel material with and without the use of coolant at different point angles is experimentally investigated. The drill bit temperature was recorded during the drilling experiment. The Feed rate and spindle speed are varied as per L14 orthogonal array. The experiments were conducted by using High Speed Steel (HSS) drills having $82^{\circ}, 100^{\circ}$ and $118^{\circ}$ drill point angles respectively. Analysis of temperature on the drilling parameters concluded that, the drilling temperature of the specimen increases with increase in both cutting speed and feed rate. This work thoroughly construes that $118^{\circ}$ drill point angle produced the highest drilling temperature during the specimen drilling. Thus in order to reduce the thermal effects during machining of the specimen, the $82^{\circ}$ drill point angle should be used.
\end{abstract}

Keywords: Thermal effect, High Speed Steel, AISI 1028 steel, Drills Angle, Cutting speed, Feed rate,

\section{INTRODUCTION}

Drilling is one of the important manufacturing operations that can be carried out on number of parts for assembly work [1] [2]. Drilling operation is essential for manufacturing industries like automobile industry, aerospace industry, medical and electrical related industries [3] [4]. Many researchers reported that the quality of the drilled surfaces depend strongly on the, drilling parameters, tool material and tool geometry [5]. Huang \& Liang [6] evaluated tool performance by calculating tool life based on the flank wear as a function of cutting conditions, that is, cutting speed, feed, and depth of cut. [1] investigated the effect of cutting parameters (cutting speed, feed rate and depth of cut) on cutting forces (feed force, thrust force and cutting force) and surface roughness in finish hard turning of MDN 250 steel using coated ceramic tool [7].

In industry, [8] main drawback is that not operating the machine tools at their optimum operating conditions so that there is loss of man power, material, time. The drilling parameters such as speed, feed and depth of cut on conventional lathe machine [9] are often selected based on the worker's experiences. However, the performance of machine and drill bit are not sure to be acceptable [10]. It has long been recognized that circumstances during metal drilling such as feed and drilling speed should be chosen to optimize the economics of drilling operations [11] [12]. Miller et al.,[13] and George et al., [14] investigated the effect of drilling parameter on low-carbon steel, aluminum and magnesium alloys on CNC vertical machine, and explored experimentally to the thrust force under different-2 spindle speeds and feed rates. In this work [15] [16] speed taken in between (5500-15000 rpm) and feed (254 - 406 $\mathrm{mm}$ ) for finding the effect of these parameter on thrust force, finally it was concluded that the work piece preheating and high spindle speed had proven to be beneficial to reduce the thrust force for friction drilling of brittle cast metals [17] [18].

Drilling of low carbon steel has shown to have some significant thermal effects on the material after the drilling operation [16]. Surface temperature of low carbon steel increases as the drilling speed increases often causing the induction of residual stress in the material [35] [36] [19]. The drilling mostly result to the material cracks [20] it was concluded that significant improvement in both productivity and product quality and hence overall machining 
economy offsetting the cost of cryogenic cooling [21]. Although low carbon has a low tensile strength which makes it easy to break under tension [14] [22], it is often heat treated making the surface harder whilst maintaining the softness and toughness of the inside. Due to its low electrical resistivity, mild steel can be coalesced with far greater ease than most metals where special techniques are needed in order to weld [23] [24]. Low carbon steel is the most commonly used steel especially when hardness is not a major concern because of its relatively low price and its material properties which satisfies many needs [24-26]. Low carbon steel can be used to manufacture a wide variety of products from home appliances and pipes to automobiles, railway lines and ship hulls [27] [28]. Therefore, it becomes increasingly necessary to identify the challenges the steel faces. When low carbon steel undergoes a drilling operation, thermal effects are often introduced to the material [29]. Aramendi et al., [30] shows that the thermal effects may cause the material to fail after a while. The effects experienced often include residual stress, surface temperature rise, was analysed [31]. This leads to more maintenance cost as repair will be needed occasionally to fix damaged parts. [32] [33] these paper studies the effects of drilling parameters such as spindle speed and feed rate on temperature which causes the induction of residual stresses during the machining of low carbon steel. Most of researchers takes the cutting parameters into consideration without looking at the of drilling angle which this work tried to investigated and justified the effect at various angles.

\section{MATERIAL AND METHOD}

The Experiments carried out on work-pieces AISI 1028 steel with chemical composition of $0.28 \% \mathrm{C}, 0.86 \% \mathrm{Mn}$, $0.040 \% \mathrm{P}$, [34] Cutting Fluids, and the experiments were conducted by using High Speed Steel (HSS) drills having $82^{\circ}, 100^{\circ}$ and $118^{\circ}$ drill point angles respectively. Low carbon steel can be recycled easily while maintaining its qualities. Its magnetic nature makes it easy to recover from mixed waste. Low carbon steel can be used to manufacture wide varieties of products from home appliances and pipes to automobiles, railway lines and ship hulls. [23] [26]. In this work an attempt has been made to develop empirical relationships to model thrust force in drilling of Multifaceted drill bit. The empirical relationships were developed by response surface methodology incorporating above drilling parameters spindle speed, feed rate and drill bit diameter.

$$
\text { Feed rate }=R P M x \text { Number of inserts in Cutter } x \text { Feed per insert }
$$

Values of Feed per insert or tooth $=0.08 \mathrm{~mm}$ and Number of inserts (tooth) in Cutter $=1$ were used. The temperature was recorded for different cutting conditions. Infrared thermometer was used in measuring the surface temperature of the work piece.

\section{RESULTS AND DISCUSSION}

Table 1. L14 Orthogonal array @ 82, $100^{\circ}$ and $118^{\circ}$ drill point angles

\begin{tabular}{cccc}
\hline Experimental Runs & Drill Diameter $(\mathrm{mm})$ & Cutting Speed $(/ \mathrm{min})$ & Feed Rate $(\mathrm{mm} / \mathrm{min})$ \\
\hline 1 & 160 & 140 & 11.2 \\
2 & 125 & 180 & 14.4 \\
3 & 100 & 220 & 17.0 \\
4 & 75 & 300 & 24.0 \\
5 & 63 & 350 & 28.0 \\
6 & 50 & 450 & 36.0 \\
7 & 38 & 580 & 46.4 \\
8 & 32 & 700 & 56.0 \\
9 & 25 & 890 & 71.2 \\
10 & 20 & 1100 & 88.0 \\
11 & 13 & 1700 & 136 \\
12 & 10 & 2200 & 176 \\
13 & 6 & 2500 & 200 \\
14 & 3 & 3000 & 240 \\
\hline
\end{tabular}


Table 2a: Temperature with respect to cutting speed and feed rate at drill point angles $82^{\circ}$

\begin{tabular}{ccccc}
\hline Experimental runs & $\begin{array}{l}\text { Temp }\left({ }^{\circ} \mathrm{C} \text { with }\right. \\
\text { coolant) with respect } \\
\text { to drill speed }\end{array}$ & $\begin{array}{l}\text { Temp }\left({ }^{\circ} \mathrm{C} \text { without }\right. \\
\text { coolant) with respect } \\
\text { to drill speed }\end{array}$ & $\begin{array}{l}\text { Temp }\left({ }^{\circ} \mathrm{C} \text { with }\right. \\
\text { coolant) with respect } \\
\text { to feed rate }\end{array}$ & $\begin{array}{l}\text { Temp }\left({ }^{\circ} \mathrm{C} \text { without }\right. \\
\text { coolant) with respect } \\
\text { to feed rate }\end{array}$ \\
\hline 1 & 38.0 & 40.0 & 38.0 & 40.0 \\
2 & 38.2 & 40.0 & 38.2 & 40.3 \\
3 & 38.5 & 40.0 & 38.3 & 40.5 \\
4 & 38.6 & 40.0 & 38.7 & 41.0 \\
5 & 38.9 & 40.2 & 38.9 & 41.4 \\
6 & 38.9 & 40.3 & 39.0 & 41.7 \\
7 & 39.1 & 40.4 & 39.1 & 41.9 \\
8 & 39.4 & 40.4 & 39.3 & 42.2 \\
10 & 39.6 & 40.5 & 39.4 & 42.3 \\
11 & 39.7 & 40.6 & 39.7 & 42.5 \\
12 & 39.8 & 40.7 & 39.7 & 42.7 \\
14 & 39.8 & 40.8 & 39.8 & 42.8 \\
\hline
\end{tabular}

Table 2b: Temperature with respect to Cutting speed and Feed rate at drill point angle $100^{\circ}$

\begin{tabular}{cllll}
\hline Experimental runs & $\begin{array}{l}\text { Temp }\left({ }^{\circ} \mathrm{C} \text { with }\right. \\
\text { coolant) with } \\
\text { respect to drill } \\
\text { speed }\end{array}$ & $\begin{array}{l}\text { Temp }\left({ }^{\circ} \mathrm{C} \text { without }\right. \\
\text { coolant) with } \\
\text { respect to drill } \\
\text { speed }\end{array}$ & $\begin{array}{l}\text { Temp }\left({ }^{\circ} \mathrm{C} \text { with }\right. \\
\text { coolant with } \\
\text { respect to feed rate }\end{array}$ & $\begin{array}{l}\text { Temp }\left({ }^{\circ} \mathrm{C} \text { without }\right. \\
\text { coolant }) \text { with } \\
\text { respect to feed rate }\end{array}$ \\
\hline 1 & 42.0 & 43.0 & 41.0 & 43.5 \\
2 & 42.1 & 43.3 & 40.8 & 43.6 \\
3 & 42.2 & 43.7 & 40.7 & 43.7 \\
4 & 42.4 & 43.9 & 40.5 & 43.9 \\
5 & 42.7 & 44.4 & 40.3 & 44.1 \\
6 & 43.0 & 44.8 & 40.2 & 44.2 \\
7 & 43.4 & 45.3 & 40.0 & 44.4 \\
8 & 43.8 & 46.0 & 40.2 & 44.5 \\
10 & 44.0 & 45.8 & 40.5 & 44.6 \\
11 & 43.9 & 45.7 & 40.7 & 44.7 \\
13 & 43.8 & 45.0 & 41.0 & 44.9 \\
14 & 43.7 & 44.6 & 41.3 & 45.0 \\
\hline
\end{tabular}

Drilling temperature is found to increase gradually with the increase in feed rate and cutting speed for drill point angles of $82^{\circ}$ with and without coolant. The temperature increases gradually at the drill point angle of $100^{\circ}$ and drops slightly at a feed rate of $176 \mathrm{~mm} / \mathrm{min}$. However, for drill point angle of $118^{\circ}$, temperature tends to rise with an increase in drill speed and marginally decreases with increasing feed rate. This shows that, temperature changes at the drill point angle of $118^{\circ}$ have a lesser effect in drilling low carbon steels when compared to $82^{\circ}$ and $100^{\circ}$ drill point angles. Agapiou \& DeVries [7], Kumar et al., [23] concluded that when thrust force and torque increases, feed rate increases as well. This feed rate increment is as a result of the expansion in the cross-sectional area of the undeformed chip. This increases the hardness and the cutting resistance of the material, which wears out the cutting tool. 
Table 2c: Temperature with respect to cutting speed and feed rate at drill point angles $118^{\circ}$

\begin{tabular}{ccccc}
\hline Experimental runs & $\begin{array}{l}\text { Temp }\left({ }^{\circ} \mathrm{C} \text { with }\right. \\
\text { coolant) with } \\
\text { respect to drill } \\
\text { speed }\end{array}$ & $\begin{array}{l}\text { Temp }\left({ }^{\circ} \mathrm{C} \text { without }\right. \\
\text { coolant }) \text { with respect } \\
\text { to drill speed }\end{array}$ & $\begin{array}{l}\text { Temp }\left({ }^{\circ} \mathrm{C} \text { with }\right. \\
\text { coolant) with } \\
\text { respect to feed } \\
\text { rate }\end{array}$ & $\begin{array}{l}\text { Temp }\left({ }^{\circ} \mathrm{C} \text { without }\right. \\
\text { coolant) with } \\
\text { respect to feed rate }\end{array}$ \\
\hline 1 & 47.0 & 46.0 & 46.5 & 50.5 \\
2 & 47.0 & 46.4 & 46.4 & 50.4 \\
3 & 47.1 & 46.7 & 46.3 & 50.3 \\
4 & 47.1 & 47.0 & 46.2 & 50.3 \\
5 & 47.2 & 47.2 & 46.2 & 50.2 \\
6 & 47.2 & 47.6 & 46.1 & 50.2 \\
7 & 47.2 & 48.0 & 46.0 & 50.1 \\
8 & 47.4 & 48.4 & 45.9 & 49.9 \\
10 & 48.0 & 48.8 & 45.9 & 49.8 \\
11 & 48.6 & 49.2 & 45.8 & 49.7 \\
13 & 49.3 & 49.4 & 45.7 & 49.6 \\
14 & 50.0 & 49.7 & 45.6 & 49.5 \\
\hline
\end{tabular}

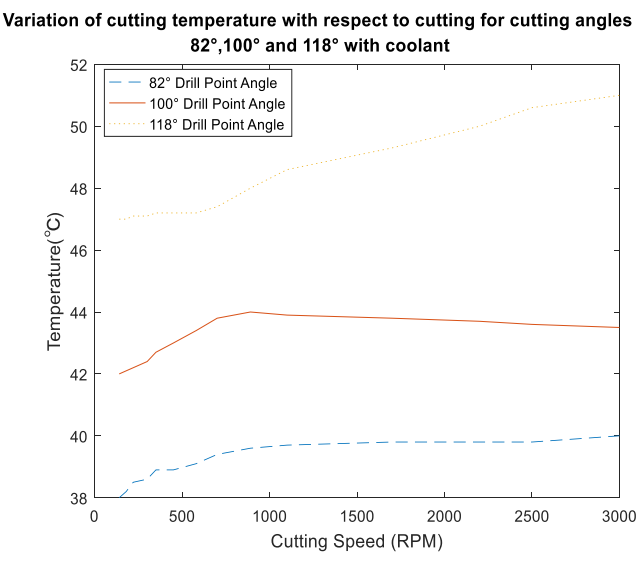

Figure 1. Cutting temperature with respect to cutting speed for different cutting angles with coolant.

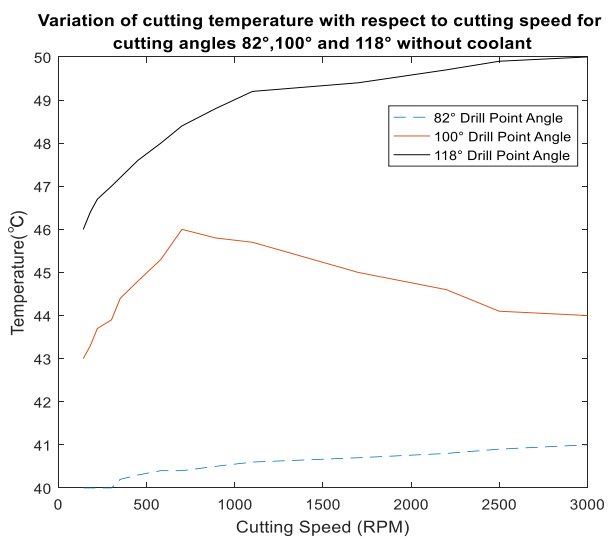

Figure 2. Cutting temperature with

for different cutting angles without coolant.

The un-deformed chip tends to melt due to increased friction at the tool-chip interface likewise increasing the temperature during the insertion of the drilling tool. It is observed from cutting speed against temperature graphs that, drilling temperature is found to increase considerably with the increase in cutting speed for all drill point angles of $82^{\circ}, 100^{\circ}$ and $118^{\circ}$ respectively. Unlike drilling with respect to feed rate; the drilling temperature for increase in cutting speed showed sizable deviation for all the drill point angles employed in the present study. The temperature changes observed during the use of coolant were much lesser when compared to drilling without its use. The sharp shape of the $82^{\circ}$ drill point angle results in the thrust force producing less friction at the tool-chip interface thus generating lower temperature during the drilling of the low carbon steel sample. Though the $118^{\circ}$ drill point angle experiences temperature drops better than the $82^{\circ}$ drill point angle, however the larger surface area around the drill point, tends to produce more friction at the tool-chip interface generating a higher temperature at the tool-chip interface during drilling of the sample. 


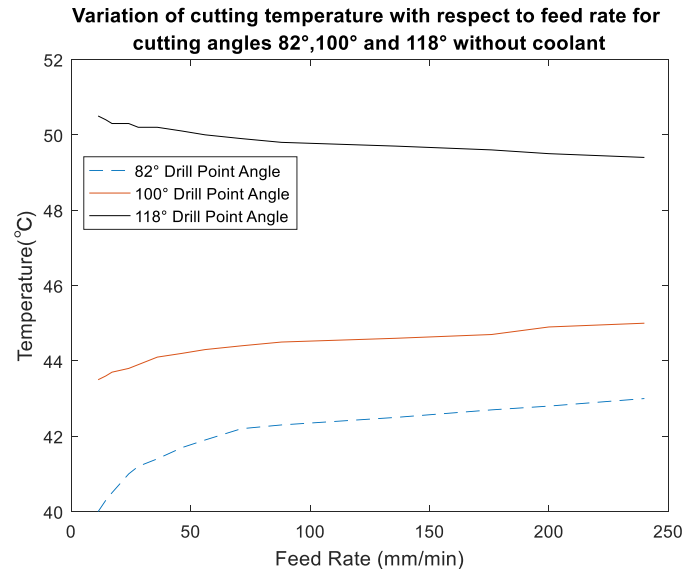

Figure 3. Cutting temperature with respect to feed rate

Different cutting angles without coolant.

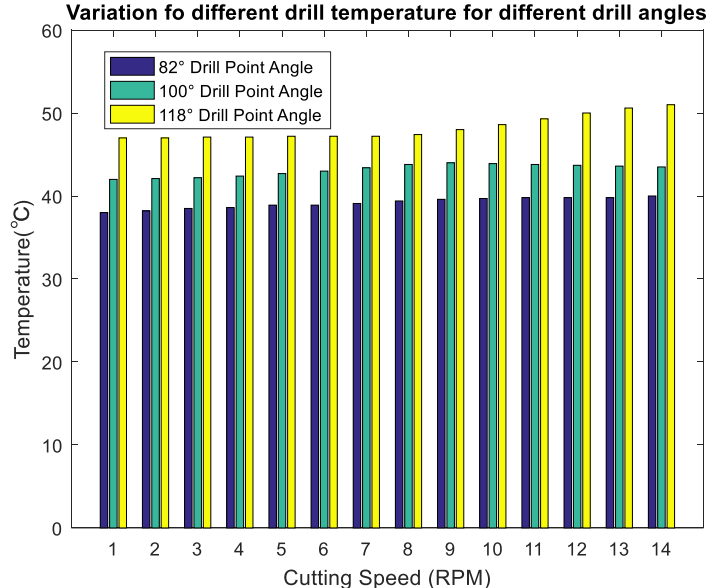

Figure 4. Temp with respect to cutting at

speed at different drill angles.

\section{CONCLUSIONS}

The $82^{\circ}$ drill point angle experiences temperature increase with respect to feed rate and cutting speed while $118^{\circ}$ drill point angle drops its temperature as cutting speed and feed rate are increased. The $82^{\circ}$ drill point angle produced the lowest drilling temperature while the $118^{\circ}$ drill point angle generated the highest. This shows that $118^{\circ}$ drill point angle produced the highest drilling temperature. Thus in order to reduce the thermal effects during machining the drilling of low carbon steel, the $82^{\circ}$ drill point angle should be used.

\section{REFERENCES}

[1] D. I. Lalwani, N. K. Mehta, Y. J. Lin, (2008) "Experimental Investigation of Cutting Parameter Influence on Cutting Forces and Surface Roughness in Finish Hard turning of MDN250 steel", journal of materials processing technology $206 \mathrm{Pp} 167-179$

[2] Archit Shrivastava (2012) Comparative Experimental Investigation for Reducing High Speed Steel Tool Wear Rate by Cryogenic Process International Journal of Scientific \& Engineering Research, Volume 3, Issue 9, September-2012 1 ISSN 2229-5518

[3] Lin T.R, (2002) Cutting behavior using variable feed and variable speed when drilling stainless steel with TiNcoated carbide drills, International J. Advance Manufacturing Technology., 19: 629-636,.

[4] B. Shivapragash, K. Chandrasekharan, C. Parthasarathy and M. Samuel, (2013), Multiple Response Optimizations in Drilling Using Taguchi and Grey Relational Analysis, International Journal ofModern Engineering Research, Vol. 3, No. 2, pp.765-768.

[5] Dhiraj V Godase, Anurag K Chavan, Dayanand A.Ghat (2016) "Parametric Evaluation of Drilling Operation of Medium Carbon Steel using Response Surface Methodology" International Journal of Mechanical And Production Engineering, ISSN: 2320-2092, Volume- 4, Issue-3,Pp70-75.

[6] Yong Huang, Steven Y. Liang. (2005) "Effect of Cutting Conditions on Tool Performance in CBN Hard Turning", Journal of Manufacturing Processes Vol. 7 No 1. 
[7] Agapiou, J. S., DeVries, M. F., (1990), On the determination of thermal phenomena during a drilling process - part I, analytical models of twist drill temperature distributions, International Journal of Machine Tools and Manufacturing, 30(2), 203-215.

[8] L.S. Ahmed and M.P. Kumar (2016). "Cryogenic drilling of Ti-6AL-4V alloy under liquid nitrogen cooling," Materials and Manufacturing Processes, vol. 31, no. 7, pp. 951-959.

[9] M. Perçin, K. Aslantas, I. Ucun, Y. Kaynak and A. Çicek, (2016) "Micro drilling of Ti-6Al-4V alloy: The effects of cooling/lubricating," Precision Engineering, vol. 45, pp. 450-462.

[10] S. Sharif, E.A. Rahim and H. Sasahara, (2012) "Machinability of titanium alloys in drilling," in Titanium Alloys-Towards Achieving Enhanced Properties for Diversified Applications, A.K.M. Nurul Amin, Ed. Osaka: InTech, pp.117-138.

[11]. Y. Tyag, V. Chaturvedi, and J. Vimal, (2012), Parametric Optimizatio of Drilling Machining Process using Taguchi Design and ANOVA Approach, Journal of Emerging Technology and AdvancedEngineering, Vol. 2, No. 7, pp. 339-347.

[12]. Jindal and V.K. Singla, (2011), Experimental Investigation of Process Parameters in drilling operation using different software technique, International Journal of Engineering Sciences, Vol. 1, No. 1, pp. 135154.

[13] S. F. Miller, J. Tao and A. J. Shih, (2006) "Friction drilling of cast metals," International Journal of Machine Tools \& Manufacture, Vol. 46, 1526-1535.

[14]. P. M George, V. J. Patel, B. P. Patel (2014), "Experimental Studies on Perpendicularity of Drilling Operation using DOE"International Journal of Advance Engineering and Research Development (IJAERD) Volume 1,Issue 3, e-ISSN: 2348 - 4470 , printISSN:2348-6406.

[15] Cicek, T. Kivak and G. Samtas, (2012), Application of Taguchi Method for Surface Roughness and Roundness Error in Drilling of AISI 316 Stainless Steel,Journal of Mechanical Engineering, Vol. 58, No. 3, pp. 122-129.

[16] Bono M, Ni J., (2002), A method for measuring the temperature distribution along the cutting edges of a drill, Journal of Manufacturing Science and Engineering, 124(4), 921-923.

[17] Agapiou, J. S., DeVries, M. F., (1990), On the determination of thermal phenomena during a drilling process - part II, comparison of experimental and analytical twist drill temperature distributions, International Journal of Machine Tools and Manufacturing, 30(2), 217-226.

[18] Agapiou, J. S., Stephenson, D. A., (1994), Analytical and experimental studies of drill temperatures, Journal of Industrial Engineering, 116(1), 54-60.

[19] J. Agapiou, D. Stephenson (1994), Analytical and Experimental Studies of Drill Temperature, ASME Transactions Trans. 54116.

[20] C. Manikandan, B. Rajeswari, (2013)" Study of Cutting Parameters on Drilling EN24 Using Taguchi Method", International Journal of Engineering Research \& Technology (IJERT) ISSN: 2278-0181, Vol. 2 Issue 7, .

[21] Chen, W.,(1996), Effect of the cross-sectional shape design of a drill body on drill temperature distributions, International Communications of Heat and Mass Transfer, 23(3), 355-366. 
[22] N. Keerthi, Dr.Syed AltafHussian (2013)"Modelling and Analysis of Machining Characteristics of En-8 Steel in Drilling Process",International Journal of Engineering Research \& Technology (IJERT) Vol. 2 Issue 11, ISSN: 2278-0181

[23] D. Kumar, L.P. Singh and G. Singh, (2012), Operational Modeling For Optimizing Surface roughness in Mild Steel Drilling Using Taguchi Technique, International Journal of Research inManagement, Vol. 2, No. 3, pp. 66-77.

[24] Azlan Abdul Rahman, Azuddin Mamat , ( 2009 )“Effect Of Machining Parameters On Hole Quality Of Micro Drilling For Brass” Modern Applied Science, University Of Malaya Research University.

[25] Kalidas, S., DeVor, R. E., Kapoor, S. G., (2001), Experimental investigation of the effect of drill coatings on hole quality under dry and wet drilling conditions, Surface Coatings Technology, 148(2-3), 117-128.

[26] Raju, B. R., Suresha, B., Swamy, R. P., Swamy, B., Kanthraju, G., (2013), Assessment of Cutting Parameters Influencing on Thrust Force and Torque during Drilling Particulate Filled Glass Fabric Reinforced Epoxy Composites, Journal of Minerals and Materials Characterization and Engineering, 1(3), 101-109.

[27] Vinod Kumar Vankanti, Venkateswarlu Ganta, (2014) “Optimization of process parameters in drilling of GFRP composite using Taguchi method” J mater. Res. technology. 3(1):35-41.

[28] Fata, B. Nikuei (2010) "The Effect of the Tool Geometry and Cutting Conditions on the Tool Deflection and Cutting Forces” World Academy of Science, Engineering and Technology Vol: 4 09-25.

[29] Jolene S. Vas, Aster Fernandes, Arnold D'Souza, Ankith Rai, Jaimon D. Quadros (2016) Analysis of Temperature Changes during Dry Drilling of Austenitic Stainless Steels on Twist Drills Having Different Point Angles Journal of Mechanical Engineering and Automation 6(5A): 121-125

[30] Gorka Aramendi, Ramón Arana, Carlos Argelich, (2008) Monitoring of drilling for burr detection using Machine Learning techniques, Innovative Production Machines and Systems, 25-32

[31] S. Chung (2005), Temperature estimation in drilling processes byusing an observer International Journal of Machine Tool and Manufacturing 45 1641-1651.

[32] Tsann-Rong, L., (2002), Cutting behavior of a TiN-coated carbide drill with curved cutting edges during the high-speed machining of stainless steel, Journal of Materials Processing Technology, 127(1), 8-16.

[33] K. Lipin,Dr. P. Govindan (2014) “A Review on Multi Objective Optimization of Drilling Parameters Using Taguchi Methods" Akgec International Journal of Technology, vol. 4, no. 2 , 11-21.

[34] Adedeji K.A (2016) 'Numerical and Experimental Investigations of Thermo-Mechanical Stress Distribution in Turning Operation’ Ph.D. Thesis, FUNNAB Nigeria.

[35] G.S. Samy and S.T. Kumaran, (2017) "Measurement and analysis of temperature, thrust force and surface roughness in drilling of AA (6351)-B4C composite," Measurement, vol. 103, pp.1-9.

[36] L. Sorrentino, S. Turchetta and C. Bellini, (2017) "In process monitoring of cutting temperature during the drilling of FRP laminate," Composite Structures, vol. 168, pp. 549-561. 